\title{
About the Urban and Bourgeois Morality of the Hindu
}

\author{
Hasan Gunes \\ Turkish Folk Literature Associate Professor \\ Anadolu University \\ Eskisehir, Turkey \\ Nadide Gunes \\ English Teacher \\ SucaaddinVeli İOO \\ Eskisehir, Turkey.
}

\begin{abstract}
Expressions like women are the "the mother of evil" (source of evil), that stealthiness is an innate born feature of women, and that men on the other hand have had to learn it much afterwards were taken word by word from Walter Rüben's “Ozean der Märchenströme. I. Die 25 Erzählungen des Dämons. (Vetalapancavimsati.) Mit einem Anhang über die 12 Erzählungen des Dede Korkut. 287 pp. 1944. FFC 133, beginning on thepage 183 "B) Über die Städter und die bürgerliche Moral der Hindu."Great effort has been spent during the translation of the due manuscript to avoid any kind of additions. Four works have been taken into consideration in the due manuscript. They are Vetālapañcaviṃsati,Vikrama-carita, ŚukasaptatiandPañcatantra. Rüben here had put forward the commercial life and besides this mentioned about the socio-cultural structure of women. This socio-cultural structure had of course been delivered by a point of view of a German. As a matter of fact persons working upon this subject, having a good deal of knowledge on it most certainly may wish to make some comments on the due subject.
\end{abstract}

Keywords: Women Vetālapañcaviṃśati,Vikrama-carita, Śukasaptati,Pañcatantra.

The brahmin public teacher Kautalyaspoke openly with the hatred of the arictrocrats, that merchants just are thieves, who only don't lead this title. ${ }^{1}$ But no state could exist without themand so it was just states dutyto control them; he needed their loan capital (116 c, 27) and took advantage of impoverished merchants of being spies (8, $14)$, that means if they were mature out of poverty for these unscrupuolus job.

In the literature of the aristocratic Brahmins merchants do not matter in general, ${ }^{2}$ but the Jains had carried it even to an art epic about a merchant. ${ }^{3}$ Jainism is just the religion of a typical Merchant. In Mbh only two of the merchant's characteristic points can be found: a glorification of a meat selling and of a vegetable Merchant. The righteous Merchant here is charged over the Brahmins, namely over the arrogant ascetic. The grengrocer (XII, 262) on his part turns himself higher over the farmer, who has to excruciate animals and slaves on plowing etc. (37 ff.) and even excruciates the earth $(45 \mathrm{f} .)^{4}$, namely he wounds with the plow. He teaches: you shouldn't cheat, or at least as little as possible (6), because even the gods have indeed a little cheated (XII, 8,28). But he especially refuses bloody sacrifice and in this way he stands in deliberate contrast to the ritualistic Vedic andsivaiticBrahamanism. The sacrificial system in his eyes isthe thievery: The pious have to give again and again $(264,5)$. The materialistic flatterer in Dasakumaracarita ${ }^{5}$ just said this and later a philosopher ${ }^{6}$ and the ascetic in Mbh XII,277, 33.

The herb Merchant however recommends plant victims $(264,33)$. But the main thing is the faith $(265,6 \mathrm{ff})$. Talking, namely praying, and action, namelyvictims areof equal value, another thrifty man says (XII, 260,6). But the Merchant also teaches that any violence ist wrong, you should let everyone, should praise them and not blame anyone $(263,11 \mathrm{f}$.), just as the logic of Jaina wasagnostic, indifferent to every thesis.You just have to understand all people, just have to be tolerant (have to serve every customer); Gentleness awakes softness (263, 24 ff.; 260 , 20). Only the meatmonger has to be dispraised $(263,42)$, the krautmerchant says. As meat merchanthere occurs the hunter. ${ }^{7}$ Meat and spice merchants used tolive in other city quarters. ${ }^{8}$ The meat Merchant defends the animal sacrifices $\left(208,5 \mathrm{ff}\right.$.) and not even blames the Kannibal Saudasasa. ${ }^{9}$ The farmer has to kill the living creatures with the plow and hoe (23). Who kills the animals are not worse than the one who kills the plants (26). 
Andeven while sitting, walking etc.everyone kills permanently small creatures (29f.); thus he teaches against the spice trader and Jainas strongly. In the nature an animal eats the other. ${ }^{10}$ The example that one fish eats the otherwas used in the Indian state of science as the struggle of all against all that has to be steamed by the governance. So here the Merchant is on the anarchist point of view that is the characteristic for the history of the literature. This Merchant explains, that not he but the Barahmis are the materialists $(264,1-5)$, and also the vegetable Merchant doesn't want to be the materialist (207, 71; 209, $26 \mathrm{ff}$.). Accordingliy neither of them talking about the core issues of materialism, the recommendation of money and fun, denial of god, the soul, the afterlife etc. they both talk about moral and ritualistic. Both are portrayed in Mbh as a model of piety. And considering that the Mbh was unclear and without a viewpoint (that is just no single fiction, but a compendium over all India), it might be considered the Indian story-literature to be a product of medieval urban or Merchant mind.It is skeptical of Brahmins and ascetics, tolerant andinconsisten in the attitude; there just wasn't on type of trader.

And you wanted not to go only a rigorous ethics with only a single path, but an ethics, which could meet all the needs and requirements of the colorful life. In all cases you have to be able to help yourself according to circumstances. That is what the Panc in one and the Suk otherwise wanted to teach. ${ }^{11}$ Accordingly sometimes the fate has been rocognized as the determining power ${ }^{12}$, but sometimes the virility or the personal ititiative ${ }^{13}$ is presented as the decisive force; but sometimes both are recommenden together (31). actually every Indian knew, that the dispute for and against the fatalism just these two keywords had chosen as the characteristics of idealists and materilists for centuries. ${ }^{14}$ You can also see a very life-like, realistic way of thinking in such "diversity"; but every ethicist as a philosopher has to condemn such ambiguous situation. This the actions are corresponding to the stories. The one who recommends the fresh courage he falls in (I, $20 \mathrm{ff}$ ), and yet no action of Panc is determined by fate, but all are dedicted by cheat. Soon the good triumphs, soon the evil. Gladly the villain speaks the language of the pious and the listeners perhaps thought it as a special charm. For example, if an evil tiger, talking with cheat, like an ascetic, a suspicious wanderer he wants to lure out lectures on that certain religious expressions and behaviours be easily used by impious deceptive so it succeeds precisely by this trick the wanderer to wheedle and later no punishment meets him. The wheedled just was greedy, had been attracted by a piece of jewellery as a gift of the tiger, wasn't suspicious enough and thus he deserved his death. This literature is a continuation of the Machiavellian political theory of Kautalya etc. And the frivolous adultery stories only should illustrate as you need to know to save yourself from every adversity even it must be done against the cuckolded husband. Can you do it, then it is allowed.

Whether the way these tales of adultery had an obscene connotation? Maybe, but it is difficult to determine. Even the love science of Vatsyayana supposedly don't want to teach the feel of pleasure. it appeals to all who earns money: The Brahmins who make it through gifts, the Kshattriyas who make it through conquest, the Vaisyas who make it through trade and the Südras who make it through prize (I, 4, $1 \mathrm{ff}$.). Vatsyayana tells of himself at the end that he had written his book in purity and highest concentration (so like a Yogi!), not to inflame the passion, but to serve the way of the world (57).He differences between love and passion. Love to be taught in addition to worship and winning as one of the three Orthodox life goals ${ }^{15}$, because by teaching the student will be free from passion, that is, he learns to control his senses. Scientific training in the economy of love just means the heart and pleasure of love. Thus this science is justified. ${ }^{16}$ But inflaming passions has played a big role in the book yet.The scholar excuses it of love but so that it is even necessary in the context of the issue and that it was always been limited right back in the book (54). It's right. He teaches for example, that kings have to be very careful of foreign woman, described initially in seduction in details and not to enter the houses of strangers (to expose themselves to any danger), also be tame and not to rape foreign women (V,5,38). Or: He initially taught the unmet harem women in all kinds of perversions as a man spare, also recommends them all kinds of cheat, how to create man people in disguise in the harem (V,6,6 ff.); but then he teaches as an antidote, how husbands should protect their harems from foreign invaders (43 ff), so as Vatsyayanas apparent brightness stands upon it: so the student learned both agents in tolerance.

For example, he also learns that the religion is more important than pleasure and profit, even if the three human goals should collide $(\mathrm{I}, 2,14)$. Only for the king and the prostitutes winning was the most important thing. A man should give up the love if it requires the consideration of the custom of the nobles $(\mathrm{V}, 1,13)$. About the woman however it may be known that such considerations play no role for her (10). Despite this piety is taught more that the lover the considerations of propriety (and religion, the comment adds) his lover could have as a married woman, should defeat by kindling and increasing their passion (44). 
Honest is the poet Asvaghosha (and he did it as a devout Buddhist easier). He describes in his literary epic of Sundaranandas love with great detail and expertise and says at the end, that he hadn't written to arouse passion but to lead to salvation, for only to attract listeners as unbelievershe had chosen this slippery subject. ${ }^{17}$ And in fact he described the love of love of Sundarananda repeatedly from the side that they make people unfree and the man to a slave of the woman ${ }^{18}$ and actually brings only suffering, pain and humiliation. A Bharthari wrote both about love and about asceticism and therefore the Indians told about the anecdote that he had become seven times buddhist but he escaped the convent again. ${ }^{19}$ and a Kaelidasa included both his Raghuvamsa and the Kumarasmbhava with detailed description of love even as a degenerated king and the other times of the god Siva own so that backer or later his copyist took offense to it apparently and the conclusions of the two art epics are missinggeven today. That was just too much. But otherwise much was adjourned in India before it was deemed to be offensive. And Kalidasa was certainly a pious man like Bahrtrhari and Asvashosha. The position to the courtesans also was ambivalent. The ruling male society loved and needed them, they might be missin in no city and the state needed them as spies and supervised them. ${ }^{20}$

This befits the idea of the Apsaras, Nymphs sent repestedly by god to the earth to seduce Hollies before they are superior the gods by their asceticism. Each Indian urban was happy by reading in Dasakumaracarita, to see how a prostitute convinced an ascetic with highly materialistic argument of the benefits of religion. ${ }^{21}$ It is the precondition for profit and love and also as constant that it couldn't be seriously endangered by all manner of violations. However, all possible gods have done things which have been impious but forthem without compromising their power in other words without compromising their power for them. Convinced also the ascetic wants to study profit and love and the whore defines it in a scientific manner pseudo and win their game she had ventured to show her art to bet a sake.

For the ascetic the woman is the principle of evil. The gods created the woman because originally all people were good and would become to gods to an Indian analogue for Pandora. ${ }^{22}$ The women the cunning were innated but the men have to learn them first ${ }^{23}$ and that is especially the materialist docrine of Usanas and Brhaspati that has inherently practical in mind of women its fixed location. ${ }^{24}$ So these famous materialistteachers have created their science from an Extract of the contents the practical reason of women. ${ }^{25}$ And Kautalya went for the women in teaching (ib). Ministers let themselves consult by their daughters (Suk $5 \mathrm{ff}$.).

On the other the hetaera will be idealized like Vasantasena and the meanness is then pushed into the matchmaker, the hetaeres mother and nun.

And finally the position of Indian writers to thieves is just as versatile (and to players). Of course the state has its courts reinserted against them and ensured that they don't stay longer in the same place ${ }^{26}$ but he tolerates and encourages them legal and illegal ${ }^{27}$. The state gets his prize from the players ${ }^{28}$ and uses brigands as privateer ${ }^{29}$, agent provocateur ${ }^{30}$ or as the last auxiliary force ${ }^{31}$ in times of need.Buddha also was born once as a robber leader ${ }^{32}$ Müladeva is portrayed as a gentleman thugSarvilaka in drama Mrcchatatikam is a learned thief but basically noble, a Brahmin by birth ${ }^{33}$ who uses his uses feisty materialist holy as a measuring line in breaking a hole in the wall at the end of the world. ${ }^{34}$ On the other hand it will be emphasized that it repents. ${ }^{35}$ He knows that he does something evil but he does it only because of poverty (III, 211)namely because he otherwise can not redeem his love, a slave of the courtesan (III, 196) so actually from love (IV, $143 \mathrm{ff}$.). He practices a pathetic selfcriticism (III, 208); but this scientifically trained thief has stolen about just this once? To excess the poet excused him: The victim is giving the intruder half asleep ignorant the jewelscasket (he holds it namely in the dark for his friend) andeven threatens him with curse if he doesn't take the casket. Accordingly, robbers were soon criticized as violent (Mbh XII, 160,7), their struggle was not recognized as heroic ${ }^{36}$ but called fraud from the trust as full. They violate the dharma (XII, 140,42) and are thorns for the humanity of which the state leadership has to free them. ${ }^{37}$ On the other hand they say in romantic shudder that even the gods fear the villain as if they were powerless for he is full of evil unevenand is not afraid of the result, regardless of whether it may be desirable or undesirable. ${ }^{38}$ And the other gentlemen thug, Apaharavarman in Dasakumaracarita, steels and loots only the rich to convince the stinginess throats of the transience of all earthly goods. He is right a bogey of the middle classes, the noblenessin person, romantic idealized as Köroğlu. But in Müladeva it has been criminally more trivialized, who is stealing and cheating in sportfor a bet and is always amiable and admirable. These crooks are prime examples of a bourgeois heroism that are in retail rebellious and deceitful but isn't in a revolutionary. They are boldly against urban and police but not in the fight. 
These remarks may suffice to show the position of the Indian urban in the middle ages the dubious elements of the society. It definitely matches the attitude of Suk and Panc. And only in contrast to them it will be clear how aristocratic the ethos of the Vet and devot of the Vikr.car. Since we don't know much about the chronology of these four famous collections it is problematic to wish to set the moral stance with it in a relationship. Panc probably can be the oldest collection of them plus it fits that still it is in its next to the old state of teaching Kautalya. As a little younger you can set the Vet and move it into the vicinity of classical Indian literature of the Gupta-term. The Suk that highly emphasizes love should have to belong to a still younger term, where love will be important relatively late as in the Greek and modern literature. The Vikr.car. is probably to be the most recent of these texts. But you may not conceive the Indian literature and cultural history naturally about as a single line development. About the possibilities to explain the differences in the literature from local differences, we can notat all say. Nor about if it has held various case these various conversations at the same time and the same place and literary designed.

\section{Conclusion}

The Literature of India has a background having its roots in very ancient times. An accumulation of culture full of treasures. From time to time Indian Literature has been an example for other literary movements, has even been the source of inspiration, or even more it has been the beginning of its source. For this reason these basic sources are of utmost importance.

Walter Rüben is an important folklorist who had seeken shelter in Turkey running away from the pressure of Hitler and had gone to India to make investigations with the support of the Turkish government. The events had been analysed and evaluated by the point of view of a German. As the due work has been present only in the German language a need has occurred to translate it into English. It is considered to be interesting regarding its subject and it is regarded to be to an important accumulation of culture and compilation.

\section{Remarks}

1 Version Jollys 77, 83.

2 They are mentioned in R I, 5, 14; II, 5, 249; Mbh I, 207, 7583

3 winternitz III, 94.

4 Compare ActaOrientalia XVII, 197; Frazer, Glodenhough V, 88 f.

5 Compare ActaOrientalia XIII, $220 \mathrm{ff}$.

6 Vacaspatimisra, Nyayavarttikatatparyatika 5,11.

7 Mbh III, $205 \mathrm{ff}$.

8 Kautalya 22, 13; 16.

9 s.o. Vet XX.

10 28: matsyanyaya; Kautalya 1 c 16 f.quoted as saying in 1001 Nights (Henning XVI, 97)

11 Compare $\mathrm{Kr} 257$ ff.

12 Hitopadesa, ed. Lassen, Proömium 26 ff.; I, 45 etc.

13 Pro. 35; I, 6; II, 3.

14 ActaOrientalia XIII, $191 \mathrm{ff}$.

15 Not salvation; comment on I, 1, 1.

16 Compare Vanderwelde!

17 Version Johnston, XVII, 63.

18 s.o. Suk.

19 Winternitz III, 140 after Itsing.

20 Kautalya 44.

21 Compare Suk 2: Fornication religious recommended!Good wife believes this finally. Compare Vet XXV, remark 13: Kanduetx. actually Indian mystics taught both Indra the king Pratardana in Kaushit. Up. Krishna Arjuna in the Bhagavatgita that killing etc is not a sin for the true mystic and Yajnavalkya already claimed in the Brh.Up. that he could not attach him sin as a mystic. what was meant at Pratardana and Arjuna as a ideological justification of the forced violent acts of the king caste it is used frivolously by Dandin. But how it is to be refuted?

22 Mbh XIII, 38ff.

23 Mrccoakatikam IV, $198 \mathrm{f}$. 
24 Hitopadesa I, 114.

25 Meyer, Translation of Kautalya LI: Mbh.

26 Kautalya 176, 21.

27 Meyer, Dasakumaracarita $21 \mathrm{f}$.

28 Kautalya 799.

29 Meyer, Kautalya 799.

30 Kautalya 80, 22.

31 ib. 118, 46.

32 Meyer, Dasakumaracarita 23 ff.; Kr 258.

33 s.o. Vet XIX.

34 In BahaesasCarudatta he does it regularly, in Mrocchatati came only because he has forgotten the measuring line

35 Lajja: IV, 208; compare Kr. 131.

36 Mrcchakatikam III, 111: saurya.

37 Kautalya III: Kanthakasodhana.

38 Kathas 121, 95; Ruthlessness applies as a virtue here.

ib. 71 and 86 . 